\author{
MAREK KORNAT \\ Instytut Historii PAN, Warszawa
}

\title{
TOŻSAMOŚĆ HISTORYCZNA MIĘDZYMORZA - INTERPRETACJE I RZECZYWISTOŚĆ
}

Według mnie regionalny podział terytorialny - tak świata, jak i Europy ma sens. Wynika on z realiów geografii. Na podstawie terytorialnych podziałów tworzą się określone kręgi cywilizacyjne, ujawniają się również i zachodzą współzależności geopolityczne. W procesie dziejowym „pierwiastek geograficzny” jest „najstarszy i od ludzkiej woli stosunkowo najbardziej niezależny" - jak pisał Marceli Handelsman w artykule Możliwości i konieczności $w$ procesie historycznym ${ }^{1}$. Wydaje mi się, że historyk nie może się bez niego obejść. Trudno byłoby zrezygnować z takich pojęć, jak Ameryka Łacińska albo Bliski Wschód. Nic by to nam nie dało, gdyby nawet taką rezygnację na historykach wymusić. Regionalne podziały oparte na podstawach geograficznych stanowią nieuniknione narzędzie postępowania badawczego historyka. Nieuchronność pewnych generalizacji to rzeczywistość pracy historyka. Oczywiście, w każdych warunkach trzeba się wystrzegać wiary w determinizm i argumentacji a posteriori - czyli tego, co jest wielką pułapką historiografii.

Niewątpliwie zdecydowana większość pojęć historycznych ma charakter konwencjonalny. Nieustające dyskusje wokół nich nie kładą kresu wątpliwościom podnoszonym wciąż na nowo. Trudno nie zauważyć, że konwencjonalność pojęć geograficznych i historycznych jest rzeczywistością, z którą zmaga się nauka historyczna nie od dzisiaj.Jak wszystkie kluczowe pojęcia historyczne - „absolutyzm oświecony”, totalitaryzm, idealizm i realizm polityczny etc. Nie upatrywałbym w tym uwarunkowaniu

${ }^{1}$ Księga Pamiatkowa celem uczczenia 350-tej rocznicy założenia Uniwersytetu Stefana Batorego w Wilnie, Wilno 1934, s. 7. 
niczego obciążającego - taka jest i, jak wszystko wskazuje na to, taka pozostanie rzeczywistość nauki historycznej.

W moim przekonaniu, postawione pytanie o czynniki kształtowania się podziałów regionalnych w historii nie pozwala na jednoznaczną odpowiedź. Z pewnością spotkamy w historii „naszej Europy” działanie wszystkich trzech wymienionych kryteriów ich tworzenia: (1) na zasadzie „samoświadomości mieszkańców danego regionu w danej epoce”, (2) na postawie wyobrażeń „wniesionych z zewnątrz przez mieszkańców innych regionów”, jak też i (3) „przez późniejszych historyków”, poszukujących w swoim postępowaniu badawczym konceptualizacji zjawisk okrywanych w przeszłości. Każda z tych możliwości jest rzeczywistością. Nie są też one skazane na opozycję. Możliwe jest ich współdziałanie.

Wyodrębnianie regionów na zasadzie „samoświadomości mieszkańców danego regionu w danej epoce" pozostaje najbardziej historycznie uzasadnione, ale to dopiero historyk analizuje i kształtuje określoną wizję przeszłości. Czyni to zawsze ex post.

Odnosząc się do czasów, które stanowią przedmiot mojej refleksji badawczej jako historyka stosunków międzynarodowych doby międzywojennej, mogę powiedzieć, że chociaż pojęcie Europy Środkowo-Wschodniej było wówczas mieszkańcom Europy między Niemcami a Rosją oraz między Bałtykiem i Adriatykiem zasadniczo nieznane, to jednak występowała bez wątpienia świadomość przynależności do Europy „Międzymorza”, czy pewnego obszaru cywilizacyjnego, który ukształtował się w następstwie Wielkiej Wojny i krachu wielonarodowych imperiów, tworzących dotychczasowy ład geopolityczny.

Jeśli chodzi o realia XX w., to osobiście opowiadałbym się za utrzymaniem w mocy pojęcia Europy Środkowej, obejmującego Polskę, Czechosłowację (Czechy i Słowację) oraz Węgry, ale stosowaniem również pojęcia Europy Środkowo-Wschodniej, które zasadniczo pokrywałoby się z pojęciem Międzymorza, tak jak było ono rozumiane w polityce i historiografii - czyli między Rosją a Niemcami oraz od Bałtyku po Adriatyk.

Spróbuję odpowiedzieć na to pytanie jako historyk XX w., skupiając się na okresie dwudziestolecia pokoju (1919-1939), jako szczególnym okresie dziejów powszechnych, co zarazem pozwoli nie wykraczać poza ramy mej specjalności.

Pojęcie Europy Środkowo-Wschodniej jest wyraźnie „młodsze” niż np. inne pojęcia dotyczące obszarów tej części kontynentu: „Europa Wschodnia” albo „Europa Środkowa”, niewątpliwie bardziej zakorzenione w nauce historycznej.

W czasie międzywojennym wyrosła wyczuwalna świadomość, że nie wystarczy określenie Europa Środkowa - jako zbyt wąskie (Polska, Czechy 
i Węgry). Obszar Międzymorza jawić się zaczął jako pewna całość. Tak też Oskar Halecki zaliczał do Europy Środkowo-Wschodniej obok Polski Europę dunajską oraz państwa bałtyckie.

Badacz uważany za twórcę terminu „Europa Środkowo-Wschodnia”, czyli Halecki, pragnął za sprawą swej nowej propozycji pojęciowej zwrócić się przeciwko tym utrwalonym w świadomości historycznej przekonaniom i pojęciom, które odmawiały Europie między Niemcami a Rosją własnej tożsamości historycznej. Pytał o tożsamość historyczną regionu, który ukształtował się w rezultacie „rewolucji geopolitycznej” w Europie po I wojnie światowej i był inny niż klasycznie rozumiana dotychczas Europa Środkowa, obejmująca zasadniczo Polskę, Czechy i Węgry. Określenia takie jak niemieckie „Zwischeneuropa” (tytuł książki Otto Forsta Battaglii z 1942 r.) albo angielskie „Lands between" - pozostają wymownym przykładem stanowiska odmawiającego temu regionowi własnej tożsamości historycznej. Halecki, jak wiadomo, sytuował Rosję poza Europą jako odrębny organizm cywilizacyjny, położony na dwóch kontynentach. Na zachód od Rosji rozciągała się Europa Wschodnia (która winna być od niej niezawisła), następnie Europa Środkowo-Wschodnia. Stworzył też pojęcie „Europa Środkowo-Zachodnia”, którym obejmował kraje niemieckie. Przynależność Europy Środkowo-Wschodniej do „cywilizacji atlantyckiej" nie ulegała jednak dla niego wątpliwości.

W wieku XX region Europy Środkowo-Wschodniej ani nie należał do „zachodnio-europejskiego centrum”, ani też nie tworzył „centrum alternatywnego".

Nowa Europa Środkowo-Wschodnia - rozumiana najszerzej, a więc jako strefa „Międzymorza”, jawiła się jako obszar peryferyjny wobec Europy Zachodniej, czyli tej właściwej. Było tak z kilku powodów.

Primo, postrzegano ją jako sferę destabilizacji, akcentując rolę czynnika lokalnych nacjonalizmów w Europie Środkowo-Wschodniej, szalejącego „egoizmu narodowego” i w ogóle „egoistycznej polityki” poszczególnych państw narodowych tego regionu. Wspomnieć może warto, iż także minister Józef Beck wielokrotnie powtarzał trafną opinię, iż po I wojnie światowej Europę Środkowo-Wschodnią „zbałkanizowano”, a określenie "l'Europe balcanisé” powtarzano często w gabinetach dyplomatycznych okresu międzywojennego, nie tylko w Warszawie. Mówiono o „szczątkach" Europy Środkowej3.

Secundo, z perspektywy teorii modernizacji akcentowano zapóźnienie

${ }^{2}$ A.W. Palmer, The Lands Between. A History of East-Central Europe Since the Congress of Vienna, London 1970.

${ }^{3}$ Sformułowanie Wladimira d'Ormessona, Moje wrażenia z Polski i Czechosłowacji, Kraków 1923 (oryg. franc. 1922), s. 11. 
cywilizacyjne tego regionu, co stanowiło dobitne potwierdzenie jej peryferyjności wobec centrum. Była to „druga Europa” - jak pisał Francis Delaisi w roku 1929 w książce Les deux Europes. Europe industrielle et Europe agricole (Paris). Autor przeprowadził na mapie Europy linię łączącą Sztokholm Gdańsk - Kraków - Budapeszt - Florencję - Barcelonę. Argumentował, że terytoria na zachód od tej linii to właściwa Europa, Europa przemysłowa, stabilna i nowoczesna, a wszystko, co na wschód od tej linii, to druga Europa - rolnicza i słabsza ekonomicznie. Poglądy Delaisiego odzwierciedlały w jakimś sensie ówczesny stan świadomości politycznej francuskich elit politycznych doby lokarneńskiej. Ich stanowisko zakładało podział Europy na dwie strefy geograficzne: Europę właściwą („Europę europejską”), czyli zachodnią, i Europę „gorszą" - szarą strefę pomiędzy Niemcami a Rosją, którą Niemcy nazywali „Zwischeneuropa”.

Już z historycznej perspektywy podobnie kreślił historię tego regionu Ivan Berend, mówiąc o „wykolejonej historii” ${ }^{4}$. Joseph Rothschild zaś pisał o „bezproduktywnie rolniczej” Europie Środkowo-Wschodniej, akcentując, że w krajach tego regionu, w okresie międzywojennym, wytwarzano jedynie osiem procent produkcji przemysłowej całego kontynentu, nie biorąc pod uwagę ZSRR ${ }^{5}$. Co zrozumiałe i powszechnie znane historykom - dyskurs o zapóźnieniu cywilizacyjnym łączył się z eksponowaniem procesu krachu demokracji parlamentarnej, która na obszarze Międzymorza ocalała jedynie w Czechosłowacji i Finlandii.

Ostrożność przy takich generalizacjach często nie jest jednak zachowywana. I tak na przykład mało się pamięta, że polski dochód narodowy - przy całej gospodarczej słabości państwa - był niewiele mniejszy w przeliczeniu na jednego mieszkańca od włoskiego, a wyraźnie wyższy od portugalskiego.

Innym ze stereotypów, który spotkamy w literaturze jako przykład „błędnych tez”, była teza Hansa Kohna, przeciwstawiającego nacjonalizm zachodnio-europejski wschodnio-europejskiemu. Ten pierwszy miał mieć charakter „obywatelski” i historyczny - ów drugi: kształtować się miał na podstawach językowych i nabrać charakteru etnicznego. Przykład Polski zaprzecza temu podziałowi, na co wskazywał już wielokrotnie historyk idei Andrzej Walicki.

Alternatywne centrum, być może, stworzyć byłaby w stanie Europa Środkowo-Wschodnia, ale w wieku XVI, w dobie dynastycznej polityki jagiellońskiej.

${ }^{4}$ I. Berend, History Derailed. Central and Eastern Europe in the Nineteenth Century, Berkeley 2003.

${ }^{5}$ J. Rothschild, East Central Europe between the Two World Wars, Washington 1974, s. 15. 
W realiach okresu po I wojnie światowej stała się obszarem oddziaływania zachodnich wzorców ustrojowych, a „wpływy polityczne Zachodu opierały się w dużej mierze na uroku i autorytecie jego cywilizacji, na powszechnej wierze w mądrość jego instytucji i obyczajów politycznych" - jak zauważył Jerzy Stempowski ${ }^{6}$. Ale to wszystko nie oznacza, że Europa Międzymorza w XX w. to Europa „mniej europejska” - lecz integralna jej część.

Podział „centrum/peryferie” może być „kompleksowy” albo „wyspowy”. Opowiadałbym się za „wyspowym”. Można by wskazać stosunkowo liczne argumenty na rzecz tej tezy. I tak np. Polska miała nowoczesne, nieustępujące w niczym krajom zachodnim ustawodawstwo socjalne, ale dalece zapóźnione cywilizacyjnie rolnictwo. Czechosłowacja była państwem industrialnym, wyróżniającym się na tle rolniczej Europy Międzymorza.

Podobieństwa między różnymi krajami naszego regionu, czyli Europy Środkowo-Wschodniej, wynikają tak z „wzajemnej bliskości geograficznej”, jak i „,z położenia peryferyjnego względem centrum”. Przede wszystkim jednak łączy narody tego regionu geopolityczna wspólnota losu, bardzo silnie widoczna $\mathrm{w}$ dobie międzywojennej - w realiach zagrożenia ze strony dążących do dominacji nad tym obszarem dwóch mocarstw totalitarnych.

Apel Handelsmana o porównawczą historię „narodów Europy Wschodniej"7 jest wciąż aktualny.

Idea pisania historii „europejskich peryferii”, w ramach której Europa Środkowo-Wschodnia pozostaje tylko jednym z obszarów zainteresowania badawczego, jest pomysłem niezmiernie interesującym. Jako postulat badawczy jak najbardziej zasługuje na uwagę.

Dyskusja nad tym, co stanowi substancjalną podstawę odrębności dziejowej Europy Środkowej, Europy Słowiańskiej czy też Europy Środkowo-Wschodniej, trwa już dziewięćdziesiąt lat. Rozpoczął ją w roku 1923 Halecki. Czeski historyk Jaroslav Bidlo pytał zaś, co tkwi „u źródeł historii Europy Wschodniej"

Pojęcie Europy Środkowo-Wschodniej jest klasyczną koncepcją stworzoną przez historiografię, ale wyraża pewną rzeczywistość, która obiektywnie zaistniała $\mathrm{w}$ dziejach. Jak wynika z moich ustaleń, pojawiło się ono zupełnie szerzej niezauważone w jednej z książek prawnika, Bohdana Winiarskiego, wydanej w Piotrogrodzie w roku 1917 pt. Międzynarodowość sprawy polskiej (s.56). W dwudziestoleciu międzywojennym nie funkcjonowało

\footnotetext{
${ }^{6}$ J. Stempowski, Europa w 1938-1939, „Ateneum” 2, 1939, 3, s. 377.

${ }^{7}$ M. Handelsman, Monde slave ou Europe orientale?, „Bulletin d'Information des Sciences historiques en Europe Orientale" 3, 1930, s. 131.

${ }^{8}$ „au fond de l'histoire de l'Europe orientale”, J. Bidlo, L'Europe orientale et le domaine de son histoire, „Le Monde slave” 12, 1935, 4, s. 1-20.
} 
w obiegu ani życia politycznego, ani nauki historycznej. Sam Halecki, będąc jednym $\mathrm{z}$ inicjatorów międzynarodowej dyskusji o miejscu naszego regionu kontynentu w dziejach powszechnych, posługiwał się terminem „Europa Wschodnia” 9 . Pojęcie „Europy Środkowo-Wschodniej” wprowadził do historiografii na nowo Halecki dopiero po II wojnie światowej, za sprawą książki The Limits and Division in European History (London-New York 1950).

W sprawie pytania, ,jak peryferia może być zarazem «środkiem»? Między czym a czym?" - moja odpowiedź byłaby następująca. Europa Środkowo-Wschodnia - tak jak rozumiał to pojęcie Halecki - nie jest peryferią Europy Zachodniej, ale obszarem o własnej tożsamości historycznej, usytuowanym pomiędzy Europą Zachodnią a Europą Wschodnią i Rosją.

W historiografii zaistniały także alternatywne koncepcje pojęciowe formułowane już po książce Haleckiego The Limits and Divisions of European History. Przypomnieć warto, iż Jerzy Tomaszewski blisko czterdzieści lat temu zaproponował posługiwanie się pojęciem „Europa Środkowa i Południowo-Wschodnia", ale jak wynika z jego ówczesnych rozważań, obejmował nim cały obszar „Międzymorza” - rozumianego jako teren geopolityczny powiązany podobieństwami gospodarczymi i podobnymi uwarunkowaniami społecznymi, jak również zmagający się z tymi samymi samymi w gruncie rzeczy wyzwaniami natury międzynarodowo-politycznej, rozciągający się między Niemcami a ZSRR oraz od Bałtyku do Adriatyku ${ }^{10}$. Znajdziemy taką terminologię pojęciową także i w Niemczech, gdzie użycie terminu „Ostmittel- und Südosteuropa” nie jest historiografii obce.

Termin Haleckiego „Europa Środkowo-Wschodnia” przyjął się w świecie anglosaskim. Najczęściej jest on tak rozumiany, że obejmuje po prostu Europę Międzymorza ${ }^{11}$. Międzymorze jest tu terytorium, którego zachodnia granica jest wschodnią granicą Niemiec, a wschodnią zachodnie rubieże Rosji.

Odpowiedź na pytanie „Co byłoby wyznacznikiem owej «środkowości», bycia "pomiędzy»?" zależy od tego, kiedy chcemy uchwycić to uwarunkowanie i w jakim czasie. Ja skupiłbym się na okresie jej realnego samostanowienia, jakie dał jej ład wersalski, czy też wersalsko-ryski.

\footnotetext{
${ }^{9} \mathrm{~Np} . \mathrm{w}$ artykule: Que-ce-que l'Europe orientale?, „Bulletin d'Information des Sciences historiques en Europe Orientale" 6, 1934, s. 82-93.

$10 \mathrm{~J}$. Tomaszewski, Europa Środkowa i Południowo-Wschodnia: cechy charakterystyczne i granice regionu, „Ekonomia” (Zeszyty Naukowe Instytutu Nauk Ekonomicznych UW), z. 36, 1976, s. 129-139.

${ }^{11}$ Zob. np.J. Rothschild, op. cit., s. IX.
} 
Historiografia zachodnia - głównie anglosaska - wskazuje właściwie przede wszystkim na cechy negatywne, będące zaprzeczeniem „zachodniości”. „Nie idee Rousseau i Jeffersona”, ale „lokalne tradycje wiejskiego życia miały określać specyfikę tego regionu" - pisał historyk amerykański Rothschild. Jego zdaniem był to obszar „,przeważająco rolniczy” („predominantly agricultural") oraz charakteryzujący się „tarciami etnicznymi” 12 . Oczywiście podnosi się fenomen zacofania - zapóźnienia cywilizacyjnego. Z perspektywy historiografii zachodniej nowa Europa Środkowo-Wschodnia - po Wielkiej Wojnie - jawiła się jako terytorium szalejącego „egoizmu narodowego".

Cytowany już Halecki dowodził, że Europa Środkowo-Wschodnia to obszar mający za sobą doświadczenie różnorodności kultur oraz doświadczenie koegzystencji wielu narodów (narodowości) w jednym organizmie państwowym. Przykłady Rzeczypospolitej Obojga Narodów oraz monarchii habsburskiej przyświecały tej argumentacji. W XX w. to ostatnie doświadczenie uległo jednak poważnemu osłabieniu.

W moim przekonaniu był to jednak obszar doniosłych procesów z punktu widzenia geopolityki - przede wszystkim w następstwie katastrofy Rzeczypospolitej w końcu XVIII w. Pisał Piotr Wandycz „rozbiory trwale zakłóciły równowagę sił w Europie, niezależnie od pozorów. Stara równowaga uległa zniszczeniu w następstwie unicestwienia Rzeczypospolitej i choć pozornie odbudowana na nowych podstawach, została zniszczona powtórnie, gdy potęga Niemiec umożliwiła im sięgnięcie po tytuł mocarstwa światowego" 13 .

Z chwilą upadku Rzeczypospolitej w końcu XVIII w. nastąpiła „,rewolucja geopolityczna” w Europie albo po prostu „rewolucja w Europie Środkowej", jak nazwał rozbiory Rzeczypospolitej brytyjski historyk Jeremy Black ${ }^{14}$. Pozbawiła Polaków własnego państwa, ale przede wszystkim zniweczyła możliwości samostanowienia regionu Europy Środkowo-Wschodniej. Wydaje się, że w wieku XIX pojęcie Europy Środkowo-Wschodniej ma sens tylko jako konstrukcja historyka, nie zaś jako rzeczywistość. W rezultacie rozbiorów na wschód od Niemiec rozciągało się tylko jedno państwo euro-azjatyckie - Rosja. Europa Środkowa uległa dominacji trzech mocarstw rozbiorowych, których koegzystencja zdeterminowała charakter stosunków międzynarodowych XIX w. „Fascynującym, choć bezowocnym,

${ }^{12}$ Idem, Return to Diversity. A Political History of the East Central Europe since World War II, New York-Oxford 1989, s. 12-15.

${ }^{13} \mathrm{P}$. Wandycz, Rozbiory Polski i dyplomacja państw zaborczych (refleksje w dwóchsetna rocznicę), w: idem, $Z$ dziejów dyplomacji, Londyn 1988, s. 42.

${ }^{14}$ J. Black, British Foreign Policy in the Age of Revolutions 1783-1793, Cambridge 1994, s. 535-536. 
ćwiczeniem umysłowym byłoby wyobrazić sobie przebieg historii Europy w XIX i XX wieku bez rozbiorów. Istnienie w sercu Europy Środkowo-Wschodniej rozległej i zreformowanej Rzeczpospolitej Polski i Litwy spowodowałoby, że większość procesów okresu napoleońskiego i ponapoleońskiego przebiegałyby w całkowicie innym kontekście. Jest oczywiste, że rozbiory zapoczątkowały reakcję łańcuchową, która - choć może się to wydać daleko posuniętą przesadą - doprowadziła do wybuchu pierwszej, a nawet drugiej wojny światowej. Rzecz jasna, pytanie zasadnicze brzmi, do jakiego stopnia rozbiory ułatwiły rozrost Prus i pozwoliły na zjednoczenie Niemiec w 1871 r. na pruskich warunkach" pisał Wandycz ${ }^{15}$. Jedynie afirmatywna odpowiedź na nie jest możliwa.

Trzeba pamiętać o współzależnościach w kształtowaniu się procesów narodotwórczych w Europie XIX stulecia, kiedy przykład narodu polskiego miał swoje oddziaływanie na aspiracje innych narodów uciśnionych. „Naród historyczny, taki jak Polacy [- - ] - pisał Roman Szporluk - stał się doskonałym modelem dla wszystkich pojawiających się narodów, którym brakowało takich warunków wstępnych, jakie mieli Polacy"16.

Przechodząc do czasów, którymi przede wszystkim się zajmowałem, pragnąłbym zwrócić uwagę na doświadczenie samostanowienia w dobie międzywojennej, w ramach ładu wersalskiego (wersalsko-ryskiego), gdyż polsko-sowiecki pokój w Rydze stanowił doniosły komponent ogólnej regulacji pokojowej w Europie Wschodniej i w ogóle europejskiej. System wersalski w Europie Środkowo-Wschodniej został wzmocniony i ocalony wskutek polskiego zwycięstwa nad Wisłą w sierpniu 1920 r. Paradoksalnie, kiedy doznała upadku „przewodnicząca rola Europy, branej jako całość”jak to ujął Bronisław Dembiński ${ }^{17}$ - Europa „Międzymorza”, pokrywająca się w zasadniczej mierze z Europą Środkowo-Wschodnią, uzyskała podmiotowość polityczną, acz na krótko. Dwudziestolecie pokoju stało się szczególnym w swym rodzaju czasem samostanowienia pozbawionych wcześniej tego prawa narodów - jednego z pierwszych praw ludzkich - prawa do identyfikacji ze wspólnotą narodową, bez opresji.

Tak się złożyło, iż region Europy Środkowo-Wschodniej odegrał kluczową rolę zarówno podczas pierwszej, jak i podczas drugiej wojny światowej.Znaczenie Europy Środkowo-Wschodniej dla geopolitycznego układu sił w świecie jest doniosłe, chociaż nie zawsze dla tych, którzy jej problemy analizują z zewnątrz. Rywalizacja Austro-Węgier z Rosją przyczyniła się do I wojny światowej. Niemiecka doktryna Lebensraumu głosiła konieczność

${ }^{15}$ P. Wandycz, op. cit., s. 42.

${ }^{16}$ R. Szporluk, Polska: powstanie teorii i praktyki nowoczesnego narodu, w: idem, Imperium, narody, komunizm. Wybór esejów, wstęp i oprac. A. Nowak, Kraków 2003, s. 39.

${ }^{17}$ BJ, B. Dembiński, „Wspomnienia 1914-1916”, rkp. akc., sygn. 62/62. 
opanowania tej części Europy, sowiecka idea „stref wpływów” wyraźnie odnosiła się do tego regionu.

Walter Lippman dowodził, że mniej więcej „od Finlandii, przez Polskę, kraje dunajskie i bałkańskie, aż do Turcji, włączając Niemcy" - biegnie strefa graniczna (borderland region) między żywotnymi interesami Rosji i takimiż interesami mocarstw zachodnich ${ }^{18}$. Europa Środkowo-Wschodnia była także terenem, z którego wyrasta geneza „zimnej wojny”. Pisał o tym kiedyś amerykański historyk Lynn Etheridge Davis w książce The Cold War Begins. Soviet-American Conflict over Eastern Europe (Princeton 1974).

W następstwie doświadczeń „pokoju wersalskiego” wspomniana już idea „bałkanizacji” zdominowała refleksję historiografii zachodniej (zwłaszcza anglosaskiej), jako koncepcja mająca uzasadnić przyczyny bankructwa całego systemu wersalskiego. W takiej perspektywie to nie ofensywa dwóch mocarstw totalitarnych i ich taktyczne przymierze w roku 1939 stanowiły decydującą przyczynę zburzenia pokoju, ale aspiracje rozmaitych „małych narodów” Europy Środkowo-Wschodniej. Trzeba tej koncepcji się przeciwstawiać. Jest to obowiązkiem historyków polskich i w ogóle historyków pochodzących z naszego regionu.

Nie państwa narodowe, jako zrealizowane prawo do samostanowienia, spowodowały niestabilność pokoju wersalskiego i „bałkanizację" regionu, ale przede wszystkim słabość i krótkowzroczność polityczna twórców tego ładu (mocarstw Ententy) oraz nade wszystko ofensywa dwóch mocarstw totalitarnych w końcu lat trzydziestych. Teoria, że organiczne wady systemu wersalskiego przyniosły niepowodzenie w postaci zburzenia pokoju w roku 1938-1939, jest efektowna, ale stanowi wielkie uproszczenie.

„Niepodległa Europa Środkowo-Wschodnia" - jak to ujął Wandycz - zrodziła się w następstwie nowej „rewolucji geopolitycznej” na naszym kontynencie w rezultacie I wojny światowej ${ }^{19}$. Obszar Międzymorza uzyskał w jej następstwie możliwość samostanowienia - bez precedensu w nowożytnych dziejach. Region ów nigdy nie osiągnął politycznego zjednoczenia. Ale występował obiektywny, naturalny związek między większością państw Europy Środkowo-Wschodniej ${ }^{20}$. Związek ów kształtowała geopolityczna wspólnota losu, którą jednak w ograniczonym stopniu uświadamiały sobie elity polityczne dwudziestolecia międzywojennego, w realiach systemu wersalskiego. Innymi słowy, jest to bardziej bezsporne dla historyka niż dla ówczesnych mieszkańców Europy Środkowo-Wschodniej.

${ }^{18}$ W. Lippman, U.S. Foreign Policy. Shield of the Republic, Boston 1943.

${ }_{19} \mathrm{P}$. Wandycz, Die Großmächte und Ostmitteleuropa vom Berliner Kongreß bis zum Fall der Berliner Mauer (1878-1989), Leipzig 2006, s. 25.

${ }^{20}$ Idem, Mała Ententa: sześćdziesiąt lat później, w: idem, Z dziejów dyplomacji, s. 130. 
Tytułem podsumowania zaważyć można, że po pierwsze, Europa Międzymorza stanowiła region „wysokiej ceny wolności” - nawiązując nieco do książki Wandycza będącej wykładem historii Europy Środkowo-Wschodniej z 1995 r. ${ }^{21}$ Po drugie, w XX w. Europa Środkowo-Wschodnia (rozumiana jako obszar Międzymorza) nie tworzyła alternatywnego centrum cywilizacyjnego, ale jednak była obszarem peryferyjnym, co nie oznacza, że pozbawionym własnej tożsamości i wartości, przede wszystkim na polu życia umysłowego.

${ }^{21}$ Idem, Cena wolności. Historia Europy Środkowo-Wschodniej od średniowiecza do wspótczesności, Kraków 1995 (oryg. ang. 1992). 